ースには結合物をつくりよく溶解した。しかしラネーニッケルは 普通の使用状態では $\mathrm{pH}$ が 9 10 であるから, この程度の弱ア ルカリ性に括ける溶解度をもとめた。 $\mathrm{C}_{6}$ 当り $1 \mathrm{~mol}$ の溶液で, $\mathrm{pH}$ を調節し，1 日放置してさらに $\mathrm{pH}$ を補正して 2 日放置し た。この操作を $2 \sim 3$ 回くりかえしてニッヶルの溶解度をもとめ たところ表 2 のよになった。

\section{表 2 弱アルカリ性溶液に括けるニッケル} の溶解度 $(\mathrm{Ni} \mathrm{mg} / \mathrm{ml})$

\begin{tabular}{|c|c|c|c|}
\hline \multirow{2}{*}{ 添 加 物 } & \multicolumn{3}{|c|}{$\mathrm{pH}$} \\
\hline & 8 & 9 & 10 \\
\hline ブ ラ ン ク & 0.02 & $0.004 \sim 0.005$ & 测定不能 \\
\hline ソルビット & 1.92 & 0.445 & 0.188 \\
\hline$\nabla \nu=\%$ & 1.25 & 0.112 & 0.055 \\
\hline グリセリン & 1.527 & 0.088 & 0.044 \\
\hline ブドウ 煻 & 1.90 & 0.085 & 0.011 \\
\hline キシロース & 2.95 & 0.098 & 0.022 \\
\hline シ $\quad$ 糖 & 1.77 & 0.06 & 0.012 \\
\hline
\end{tabular}

すなわちソルビットが他の糖類, 多価アルコールに比して弱ア ルカリ性に括ける溶解度がきわめて大で, ソルビットが他のアル コールに比して，製造時にニッケルを多く溶解する事実と一致し た。

高アルカリでニッケルを多く溶解する糖類, 多価アルコールが 必ずしも低アルカリで, ニッケルを多く溶解するとは限らなかっ た。

\section{3 考察}

糖類あるいは多価アルコールの溶液にニッケル塩を加え, 水酸 化ナトリウムを加穴て液をアルカリ性にすると，ニッケルがよく 溶解する場合がある。よく溶解する場合は, 溶解後 1 時間位で約 90\%のニッケルが糖類あるいは多価アルコールと安定な化合物 をつくり，放置すると汪とんど全部のニッケルが安定に化合して 溶解したものと思われる。ニッケルの割合が多いと組成不明のゲ ルとなり,さらにニッケルの割合が多くなると, 全部のニッケル を溶解することができなくなる。

ソルビット，マンニットのニッヶル化合物の溶液にメタノール を加えて得た沈殿は乾燥すると $\mathrm{C}_{6} \mathrm{H}_{14} \mathrm{O}_{6} \cdot n \mathrm{NiO}$ に相当し, ソル ビットでは $n$ が $1.3 \sim 2.5$ で，マンニットでは約 $1.8 \sim 2.2$ であ り, 両者のモル比は簡単な整数比は得られず, 溶解しているニッ ケルは, これらアルコールと単一化合物をつくっているのではな く, 数種類の化合物の混合物と見なされる。またいくらかゲル化 の傾向を有する。

また低アルカリでソルビットのみが他の糖類, 多価アルコール に比してニッケルをよく溶解したが，ソルビット製造時に、、ン ニット, キシリットに比し還元された溶液が強く緑色に着色して いる事実と一致した。

（昭和 40 年 7 月, 日本化学会北海道大会で一部発表)

また本研究で種々と御指導を賜わった早稲田大学・武富界教授 に謝意を表する。

尿素, リン酸によるリン酸セルロースの生成反応*1

(昭和 40 年 10 月 1 日受理)

\author{
勝浦 嘉久次・稲 堭 訓 宏林
}

\begin{abstract}
尿素, リン酸によるリン酸セルロースの製造に拈ける副反応を追求し，採用した条件下ではイソシアン酸 $\mathrm{HN}=\mathrm{C}=\mathrm{O}$ の生成，掠 よびそれに基づくリン酸の縮重合反応が主なるのであることを明らかにした。

また，リン酸のエステル化と縮重合の主副両反応の相関関係を明らかにするため, 正りン酸, リン酸二水素ナトリウム，扣よび ポリリン酸をエステル化剂として実験を行なった。実験結果によると, リン酸の縮重合反応はセルロースが共存すると全部が高度 のポリリン酸とならない状態で平衡に達し，またその平衡状態はェステル化剤の種類，反応温度によって異なる。エステル化は縮 重合反応とほほ平行に起り，縮重合反応の起りにくいリン酸二水素ナトリウムではェステル化反応もまた最も起りにくい。またポ リリン酸のとき最もェステル化は起りやすいが，縮重合反応とェステル化反応との関係は正リン酸とポリリン酸の場合特に複雑で ある。
\end{abstract}

\section{1 緒言}

尿素, リン酸によるリン酸セルロース製造法は比較的試料の解 重合が少ないことと架橋結合を有しない二塩基酸型エステルとな る点で特徴があり ${ }^{1)}$ ，また，そのアンモニウム塩が難然性を示す

*1 本研究を「リン酸セルロースの研究（第 5 報）」とする。 第 4 報は紻学誌, 21, 399 (1965).

*2 Kakuji KATSUURA, Norihiro INAGAKI 静岡大学工学部 工業化学教室 : 浜松市追分町.

1) 勝浦, 野中, 㵶学誌, 13, 24 (1957).

2) たとえば, J. David, L. W. Mazzeno, Jr., Ind. Eng. Chem., 41, 2828 (1949).
点で興味のある物質である2)。この製造法の反応機構に関しては 若干の研究が発表されているが3,4)，まだ不明の点も少なくない。 一方, 尿素, リン酸を加熱するとリン酸の縮重合反応, 尿素の分解 反応など種々の反応が起こり，これらはポリリン酸の製造に関係 寸るものとして研究が行なわれている5)。しかし，これらの反応 はリン酸セルロ一ス製造の立場からみても重要な反応であり, こ

3) E. V. Davis, J. Findley, E. Rogers, J. Text Inst., 40, T 839 (1949).

4) A. G. Nuessle, F. M. Ford, W. P. Hall, A. L. Lippert, Text. Res. J., 26, 32 (1956).

5) 植田，尾山，小間，工化，66，586 (1963). 
れらの反応の相関関係を十分検討して扰く必要がある。

著者らは，採用した反応条件下でいかなる副反応が起きている かについて改めて考察を加えるととるに，特に主反応に著しい影 響をあた学ると考えられるリン酸の縮重合反㐫を主反㐫と対比し て検剖を行なった。これらについて報告する。

\section{2 実験}

\section{$2 \cdot 1$ 反応方法}

まず，採用した反応方法を記すと次のと和りである。すなわち $\mathrm{SP}$ パルプを家庭用ミキサーで 2 分間粉砕し, 広口ビン中で一週 間以上密栓して水分を一定としたものをセルロース原料とし，そ の $4.5 \mathrm{~g}$ （水分 $10.0 \%$ ）を尿素 $38.9 \mathrm{~g}, 85 \%$ 正りン酸 $28.9 \mathrm{~g}$, 水 $29.5 \mathrm{~g}$ の浸せき浴中に一昼夜浸せきし，七ルロ一ス重量の 5 倍に圧さくする。浸せき液より計算した圧さく後の組成はセルロ 一ス 1 基本 $\mathrm{mol}$ に対し, リン酸 $1.5 \mathrm{~mol}$, 尿素 $4.0 \mathrm{~mol} ゙$, 著 者らの今までの実験でほぼ最適と考光られる組成 ${ }^{1)}$ と一致してい る。压さく物はよくほぐし三つロフラスコ中で窒素ガスを通しな がら油浴中 $105^{\circ} \mathrm{C}, 2$ 時間乾燥し, さらに還流冷却器をつけて, $130^{\circ} \mathrm{C}$ または $150^{\circ} \mathrm{C}$ で適当時間反応させた。また，リン酸成分 としては，i）上述の正リン酸のほか，ii）縮重合反応を持こし にくいといわれているリン酸二水素ナトリウム $\left(\mathrm{NaH}_{2} \mathrm{PO}_{4}\right)$ 拈よ び iii）すでに縮重合を执こしているポリリン酸, を正リン酸の 場合と同じモル比で反応させた。な抒, 正りン酸, リン酸二水素 ナトリウムは市販品試薬 1 級を, また, ポリリン酸は予備実験で はリン化学工業（株）製品*3 115\% のものを，また，本実験では $58 \%$ 正リン酸 $100 \mathrm{~g}$ を加熱し，これに無水リン酸 $131 \mathrm{~g}$ を少量 ずつ加えて完全に溶解させて $115 \%$ ポリリン酸としたものを使 用した。このものの分析值は表 3 に示してある。

また，植田ら ${ }^{5)}$ によると尿素，リン酸混合物は $140^{\circ} \mathrm{C}$ 以上の加 熱により，尿素の熱分解とリン酸の縮重合反応を扎こすとのこと であるから，反応温度としては上述の $140^{\circ} \mathrm{C}$ 前後の $130^{\circ} \mathrm{C}, 150$ ${ }^{\circ} \mathrm{C}$ を採ることとした。

\section{$2 \cdot 2$ 分 析}

反応開始後適当時間ごとに反応生成物約 $300 \mathrm{mg}$ をと出 し，水を加えて $50 \mathrm{~m} l$ として上ずみ液を E. Karl-Kroupa の方 法6)にならい, また，植田らの方法卓を参考としてペーパークロ マトグラフにかけ，さらに，それより各縮合リン酸を光電光度計 （日立 FPW-4 型使用）をつかって定量した。リン酸セルロース は副生成物を除去後, そのまま，または，ナトリウム塩として精 製し、リン拉よび窒素をそれぞれリンモリブデン酸法, デュマス 法で分析した。また，正リン酸を使用した場合について各種定性 分析, 赤外線吸収スペクトル測定 (日本分光 IR-S 型使用)によ って副反応を解析した。

なお，実験的に定めた純粋な各種りン酸の $R_{f}$ 值は表 1 のと特 りであるが, 便宜上以後はトリリン酸以上をポリリン酸として表

表 1 各種リン酸の $R_{f}$ 実験值

$\begin{array}{llll}\text { 正リン酸 } & 0.73 & \text { トリリン酸 } & 0.33 \\ \text { ピロリン酸 } & 0.48 & \text { テトラリン酸 } & 0.22\end{array}$

わすこととする。

*3 試料を恵与されたリン化学工業株式会社研究部の御厚意に 感謝します。

6) E.Karl-Kroupa, Anal, Chẹm., 28, 1091 (1956),

\section{3 実験結果および考察}

311 リン酸セルロース生成にともなう各種副反応の推定

まず尿素，正リン酸，セルロースの伈系についてどのような 副反応が括こっているかを検㴊した。

尿素と正リン酸を混合して加熱した場合，次のような反忘のお こる可能性がある。

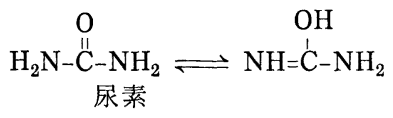

$$
\begin{aligned}
& \mathrm{OH} \\
& \begin{aligned}
\mathrm{HN}=\mathrm{C}-\mathrm{NH}_{2} \longrightarrow \mathrm{HN}=\mathrm{C}=\mathrm{O}+\mathrm{NH}_{3} \\
\text { イソシアン酸 }
\end{aligned} \\
& \mathrm{HN}=\mathrm{C}=\mathrm{O}+\mathrm{H}_{2} \mathrm{O} \longrightarrow \mathrm{NH}_{3}+\mathrm{CO}_{2}
\end{aligned}
$$

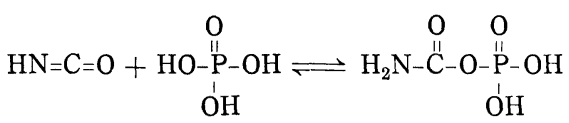

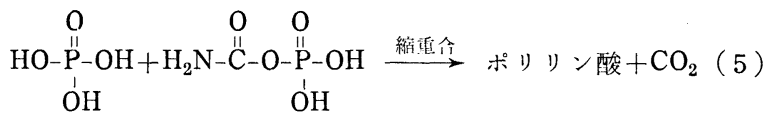

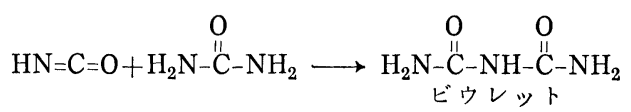

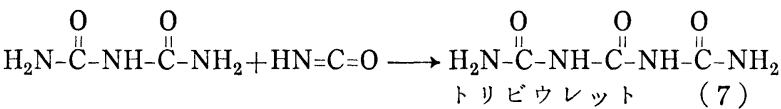<smiles>[Y][Y6]1([H])C(O)=NC=NC1(O)[18OH]</smiles>

（2）のイソシアン 酸生成反呂は酸によって促進されるといわ れており7，この場合の条件もそれと合っている。また，周知の ようにイソシアン酸は非常に不安定で, 少鼠の水の存在によって （3）のよ5にアンモニアと炭酸ガスに分解し，また，さらに植 田ら 丂に反応して，ポリリン酸のアンモニウム塩と炭酸ガスを生成す る。本実験に和いても（3）の反応は $110^{\circ} \mathrm{C}$ 付近からの炭酸ガス の発生により，また（4)，（5）の反心は後述のようにポリリ ン酸の生成によって確認することができる。

反応生成物の水溶液についてビウレット反応テストを行なった ところいずれの場合も陰性であり，また，（8）のシアヌル酸は 水に難溶性であるが，本実験に打ける反応生成物はすべて水に可 溶である点から（6），（7），（8）の各反応はこの場合は括こっ ていないるのと考兄られるな怙，セルロースが共存しないとき の㽷素, リン酸からのシアヌル酸の生成は $140 \sim 150^{\circ} \mathrm{C}^{5)}$ でも, またより高温の加熱 $\left(175^{\circ} \mathrm{C}\right.$ 以上 ${ }^{3)}$ または $\left.220^{\circ} \mathrm{C}^{4)}\right)$ であみとめ られているが，七ルロースが共存すると上述のようにこれらとは らがった結果となる。

また，尿素とセルロースとの反応として，次の反応が考吕れ る。

7)たとえば, 向山，化学と工業，17，13 (1964), 


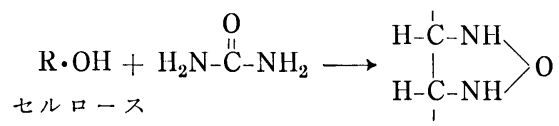

$$
\begin{array}{cc}
\mathrm{R} \cdot \mathrm{OH}+\mathrm{HN}=\mathrm{C}=\mathrm{O} & \stackrel{\mathrm{N}}{\mathrm{N}} \\
\text { セルロース } & \text { R-O-C } \mathrm{NH}_{2} \\
\text { 七ルロースカーバメイト }
\end{array}
$$

（9）の反応はセルロース中の $\mathrm{C}_{2}, \mathrm{C}_{3}$ の水酸基の ところで拈 こる反応であるが，Segal ら ${ }^{8)}$ も述べているよ5に $240^{\circ} \mathrm{C}$ 以上 つ高温，抢よび大気圧以上の圧力を必要としこの場合は考兄る必 要はない。また，セルロースを尿素水溶液に浸せきし，140〜170 C に加熱するとイソシアン酸を経て（10）に示す上万にセル口 一スカーバメイトが生成し，窒素含有量 1 ～ $2 \%$ となるが，これ さ $2 \%$ カセイソーダで 30 分間煮沸すると分解して窒素は零に まるといわれている8)。一方，リン酸セルロースは反応浴から水 先によって, $\mathrm{R}-\mathrm{O}-\mathrm{O}-\mathrm{P} \underset{\mathrm{P}}{\mathrm{O}} \mathrm{OH}$ リウム塩とすると簡単に R-O- $\mathrm{O}$ P $\mathrm{O}$ ONa

本実験の場合正りン酸を使って反応させた場合の水洗と $2 \%$ カ イソーダ処理に猢るる結合リン，結合窒素の変化は表 2 のよ $5 に$ なるが，尿素，七ルロースのほかにリン酸が関係する本実験の場 今窒素の変化のみから，七ルロースカーバメイトの生成を推定す

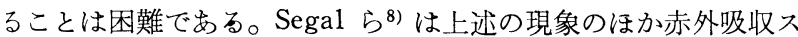
ペクトルによってセルロースカーバメイトの生成を確認している 3゙，著者らの赤外吸収スペクトルの結果では $5.80 \mu$ のカルボニ ル基の吸収がみられず（10）の反応を確認することはできなかっ ro

\begin{tabular}{|c|c|c|c|c|c|}
\hline \multirow{2}{*}{$\begin{array}{l}\text { 反応 } \\
\text { 温度 } \\
\text { (C) }\end{array}$} & \multirow{2}{*}{ 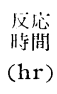 } & \multicolumn{2}{|c|}{ 水沙精製 } & \multicolumn{2}{|c|}{$\begin{array}{l}2 \% \text { カセイソーダ } \\
\text { 处理後水沈精製 }\end{array}$} \\
\hline & & P\% & $\mathrm{N} \%$ & $\mathrm{P} \%$ & $\mathrm{~N} \%$ \\
\hline \multirow{5}{*}{130} & 0.5 & 0.9 & 0.5 以下 & 0.8 & 0 \\
\hline & 1.0 & 1.7 & 0.6 & 1.7 & $"$ \\
\hline & 2.0 & 2.0 & 1.0 & 1.9 & 11 \\
\hline & 3.0 & 2.2 & 1.3 & 2.0 & $" 1$ \\
\hline & 7.0 & 3.0 & - & 2.7 & - \\
\hline \multirow{5}{*}{150} & 0.5 & 1.4 & 0.5 以下 & 1.5 & 0 \\
\hline & 1.0 & 2.1 & 1.1 & 2.0 & $1 "$ \\
\hline & 2.0 & 2.3 & 1.0 & 2.3 & "I \\
\hline & 3.0 & 2.4 & 1.2 & 2.4 & 11 \\
\hline & 7.0 & 2.7 & - & 2.4 & - \\
\hline
\end{tabular}

表 2 精製によるリン酸セルロース中の結合リン および結合窒素の変化

以上を総合すると副反応としては（2）のイソシアン酸から出 発する（3)，(4)，（5）の反応が問題となり，副反応生成物と して, 反応浴中に残るるのとしては（5）が考完られることにな る。（10）の反応は不確実であるう党量的もも多くなく，また， アルカリ精製によって除去されてしまう。したがって，次に（5) のリン酸の縮重合反応と主反応との関倸について，さらに検討を 㞦党ることとする。

\section{$3 \cdot 2$ リン酸セルロースの生成反応とリン酸の縮重合反応との}

関係

上述の 3 種のリン酸化剂を使った場合の縮合リン酸のペーパー クロマトグラフによる結果, 执よびセルロースへのリン結合量の 分析值上り図 1 3 が得られる。すなわち，図 1 3 は各リン酸 化剤を使った場合の正りン酸，ピロリン酸，ポリリン酸，打よび

8) L. Segal, F. V. Eggerton, Text. Res. J., 31, 460(1961).

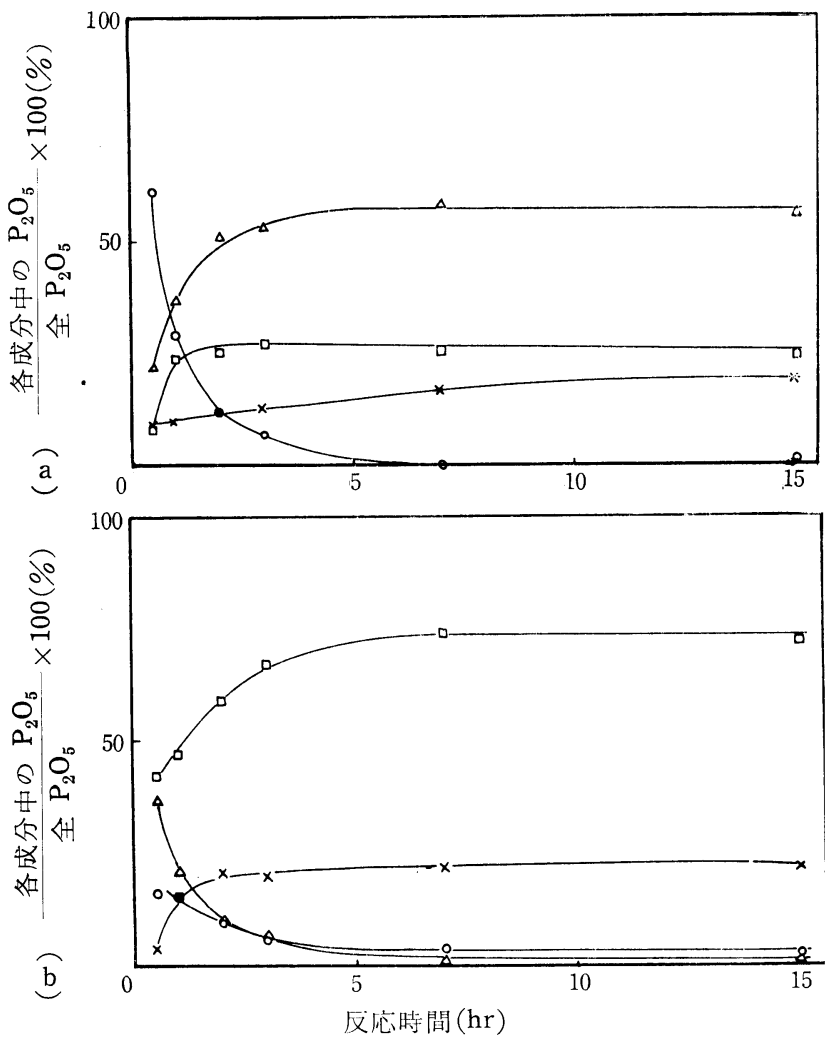

因 1 リン酸のエステル化反応と縮重合反応の関係 (正りン酸使用の場合)

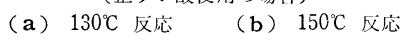

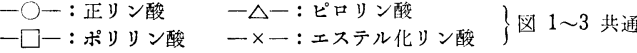
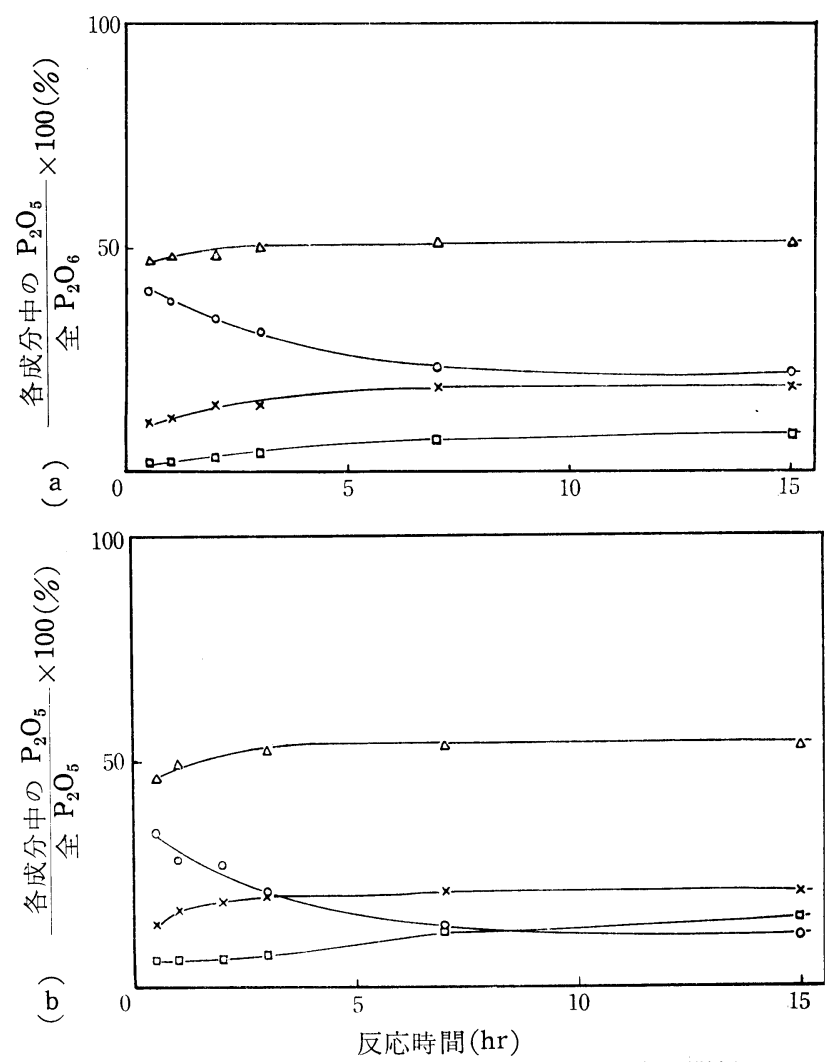

図 2 リン酸のエステル化反応と縮重合反応の関係

（リン酸二水素ナトリウム使用の場合）

(a) $130^{\circ} \mathrm{C}$ 反応 (b) $150^{\circ} \mathrm{C}$ 反応 

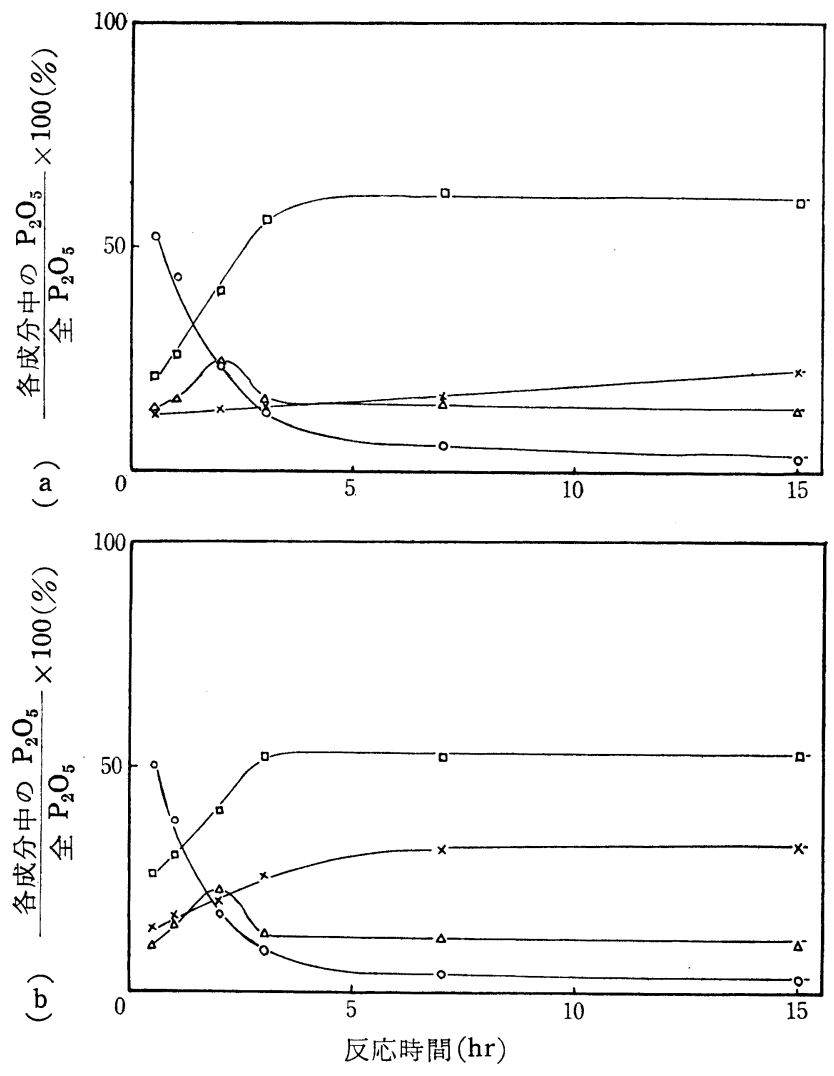

図 3 リン酸のエステル化反応と縮重合反応の関係 (ポリリン酸使用の場合)

(a) $130^{\circ} \mathrm{C}$ 反応 (b) $150^{\circ} \mathrm{C}$ 反応

結合リン酸の百分率の経時変化を示したものである。また, リン の総量は反応時間によって変わらないから, 各曲線の変化は各成 分の量の変化をあらわしている。ただしすべて， $\mathrm{P}_{2} \mathrm{O}_{5}$ として計 算してあり，また，各㘠番号の添字 $\mathrm{a}$ は $130^{\circ} \mathrm{C}, \mathrm{b}$ は $150^{\circ} \mathrm{C}$ 反 応を表わしている。

図に明らかなようにリン酸の縮重合反応はセルロースが共存す ると, 全部が高度のポリリン酸とならない状態で平衡に達し，尿 素，リン酸の混合物が $140 \sim 160^{\circ} \mathrm{C}$ の加熱で数分間で高分子化す るといわれている5 のとは対照的な変化を示している。また，リ ン酸二水素ナトリウムはセルロースが共存する場合も最も縮重合 を特こしにくく，ピロリン酸の生成が全体の $50 \%$ 程度のところ で平衡に達する。な拉 $115 \%$ のポリリン酸を使用するときはセル ロースをポリリン酸, 尿素, 水の混合液に一昼夜浸せき放置する 操作中にポリリン酸の加水分解が括こり, 表 3 の上うな組成变化 を拈こしている。したがってポリリン酸を使用する場合と正リン 酸を使用する場合との差は小さくなっている。しかし, 図 1 と困

\section{表 3 115\% ポリリン酸の組成}

\begin{tabular}{|c|c|c|c|}
\hline & $\begin{array}{l}\text { 正yン酸 } \\
(\%)\end{array}$ & $\begin{array}{l}\text { ピロ リン } \\
\text { 酸 }(\%)\end{array}$ & $\begin{array}{l}\text { ポリリン } \\
\text { 酸 }(\%)\end{array}$ \\
\hline 段調製時の組成*4 & 7.4 & 12.4 & 80.2 \\
\hline $\begin{array}{l}115 \% \text { ポリリン酸 } 24 \text { 洔間放置後の組成 } \\
\text { (いずれま } \mathrm{P}_{2} \mathrm{O}_{5} \text { として算出) } \\
\text { (いず }\end{array}$ & 68.0 & 29.2 & 2.8 \\
\hline
\end{tabular}

*4 調製時の組成は文献値 ${ }^{9)}$ とよく合っている。

*5 $115 \%$ ポリリン酸 $23.8 \mathrm{~g}$, 尿素 $24.4 \mathrm{~g}$, 水 $48.9 \mathrm{~g}$ を室 温一昼夜放置した場合で，このモル比は 2.1 の場合と一 致している。

9) J. R. Van Wazer, "Phosphorus and its compounds “ vol. 1, Interscience, New York (1958), p. 748.
3 とでは明りょうに差が認められ，特に $130^{\circ} \mathrm{C}$ 反応のときその差 が顕著である。すなわち $130^{\circ} \mathrm{C}$ 反応のとき正りン酸の場合(図 1 a) 図は縮重合が括こりにくく，リン酸二水素ナトリウムの場合 （図 $2 \mathrm{a} ， 2 \mathrm{~b}$ ) と同様ピロリン酸の生成が最も多いのに対し， 小 リリン酸のとき（図 $3 \mathrm{a}$ ) はポリリン酸の生成が最も多くなって いる。しかし， $150^{\circ} \mathrm{C}$ 反応では正りン酸，ポリリ:酸いずれのと きもポリリン酸の生成量が最も多い(図 $1 \mathrm{~b}, 3 \mathrm{~b}$ )。また, $150^{\circ} \mathrm{C}$ 反応に拈ける両者間ではポリリン酸よりも，すなわちポリリン酸 から一度加水分解して再び縮重合を扣こすよりる，はじめから正 リン酸を使用した場合（図 1 b) の方がポリリン酸の生成量多く, 縮重合反応る速いことが認められる。な技, リン酸の縮重合反応 は反応温度によって差があるはずであるから， $130^{\circ} \mathrm{C}$ と $150^{\circ} \mathrm{C}$ と では著者らがポリリン酸と定義したものの内容に差のあることは 注意する必要がある。

一方，リンの縮重合反応とエステル化反応との関倸については，

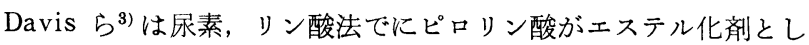
て働くといっており，また最終生成物は正りン酸のエステルであ ることを認めている。また別に縮合度 $2 \sim 4$ のポリリン酸がアル コールのエステル化剂として作用するとの文献 ${ }^{10)}$ ある。一方, 前に検討した副反応 (4)，（5）の縮重合反応と同じょうに（4） を経て次のようなセルロースのエステル化反応 (11) の抗こる可

$$
\begin{aligned}
& \mathrm{O} \quad \mathrm{OH} \quad \mathrm{ONH}_{4}
\end{aligned}
$$

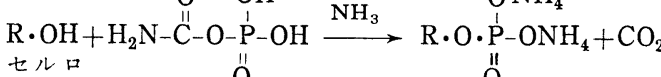

$$
\begin{aligned}
& \text { 世 } \\
& \text { O } \\
& \text { OI }
\end{aligned}
$$

能性も十分存在する。すなわち, 正りン酸からエステル化と縮重 合の両反応が同時にはじまると考えることもできる。しかしピ口 リン酸などについても同じょうな反応を考えることができ，図 3 $\mathrm{a}$, 図 $3 \mathrm{~b}$ のピロリン酸の変化に極大があることもこの傾向を支 持しているが，図 1〜3 の結果は複雑で全般的な両反応の相関関 係についてこれ以上立ち入った結論を出すことは困難である。な 扮縮重合反応の括こりにくいリン酸二水素ナトリウムはエステル 化剤としても最も反応性が小さく，上の結果と考光めわせると縮 重合反応を持さえることはェステル化反応をも抑制することにな ることは確かである。

次に図 1〜3 から結合リン \% の経時変化を $130^{\circ} \mathrm{C}, 150^{\circ} \mathrm{C}$ に ついてそれぞれ一括して図示すると図 4, 図5 のよ5になる。

$130^{\circ} \mathrm{C}$ 反応の場合多少の混乱はあるが，傾向としてはいずれの 反応時間のときも，ポリリン酸のときが最も反応性が大きく，ま

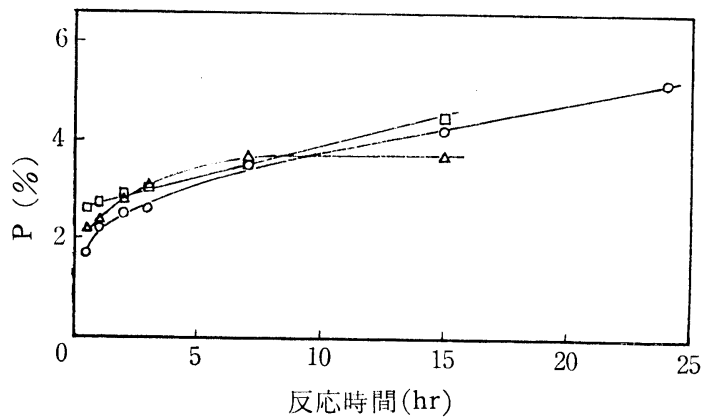

図 4 リン酸化剤と結合リン \% の関係 $\left(130^{\circ} \mathrm{C}\right.$ 成心の場合 $)$

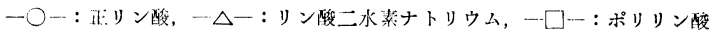

10) D. M. Brown, "Advance in Organic Chemistry" vol. 3, Interscience, New York (1963), p. 107. 


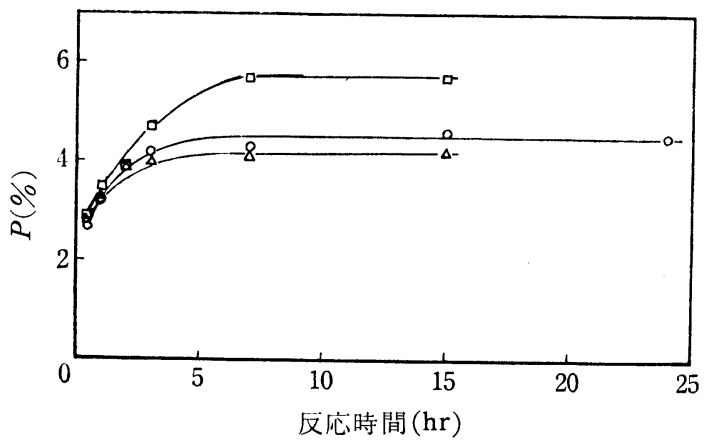

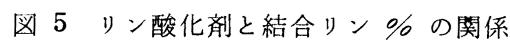
(150ㄷ 反心場合) 記号は图 4 と同じ

た一般に $150^{\circ} \mathrm{C}$ の方が短時間で高い $\mathrm{P} \%$ のところで平衡に達す る。ポリリン酸の場合反応前に一度正リン酸などに解重合し，そ
れから再び縮重合およびェステル化を開始するが，一般にポリリ ン酸のエステル化が最す抗こりやすいということは，このように して生成した正リン酸などははじめから正りン酸として存在する ものよりエステル化に関し活性度が高いことを示し興味がある。 また縮重合反応に関しては両温度で正リン酸, ポリリン酸を使用 したときの変化は互いに異なる傾向を示している。これは反応温 度によって縮重合反応の内容に差のあることにもよるがくわしく は今後の問題としたい。

（昭和 39 年 5 月および昭和 40 年 5 月, 繊維学会春期大会に それぞれ一部講演）

終りに本研究に熱心に協力してくださった坂口正治氏に深く感 謝します。

\section{ポリカーボネートの溶液性 状}

（昭 和 40 年 11 月 10 日 受 理)

寺町 信哉・高 橋 彰・香川 艈美*1

ポリカーボネート（ポリ-4, $4^{\prime}$-ジヒドロキシージフェニル-2,2-プロパンーカーボネート）を，sym-テトラクロルエタンーnーヘキ サン系で分別した。そのいくつかの区分について，1，2-ジクロルェタン溶液 $\left(25^{\circ} \mathrm{C}\right)$ の光散乱測定により分子量を決定し，また，

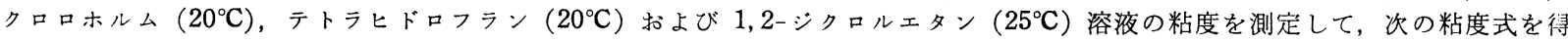
た。

(1) $[\eta]=2.45 \times 10^{-2} \cdot M_{\mathrm{W}}{ }^{0.75} ;$ クロルホルム $\left(20^{\circ} \mathrm{C}\right)$

(2) $[\eta]=3.55 \times 10^{-2} \cdot M_{\mathrm{W}}^{0.71} ;$ テトラヒドロフラン $\left(20^{\circ} \mathrm{C}\right)$

(3) $[\eta]=4.01 \times 10^{-2} \cdot M_{\mathrm{W}}{ }^{0.69}{ }_{5} ; 1,2$ ジクロルェタン $\left(25^{\circ} \mathrm{C}\right)$

$\Theta$ 溶媒の探索を行ない，単独溶媒では $\Theta$ 溶媒を見いだせなかったが， $30^{\circ} \mathrm{C}$ に拈ける sym-テトラクロルエタンーnーヘキサン

（46.1:53.9 体積比）系が $\Theta$ 溶媒であることを見いだした。この溶媒中で粘度測定を行ない，次の結果を得た。
(4) $[\eta]=2.30 \times 10^{-1} \cdot M_{\mathrm{W}}{ }^{1 / 2}$
(6) $\left(\bar{r}_{0}\right)^{1 / 2} / M^{1 / 2}=929 \times 10^{-11}$
(5) $K_{\theta}=0.230\left(\mathrm{~cm}^{3} \cdot \mathrm{mol}^{1 / 2} \cdot \mathrm{g}^{-1 / 2}\right)$
( 7) $\sigma=1.16$

上記の（1）（3）について，倉田-Fixman プロットを行ない，

(8) $K_{\theta}=0.230\left(\mathrm{~cm}^{3} \cdot \mathrm{mol}^{1 / 2} \cdot \mathrm{g}^{-1 / 2}\right)$

を得た。

クロロホルム溶液について, 第 2 ビリアル係数 $A_{2}$ の温度依存性を測定し，それから，次の結果を得た。

(9) $\Delta \mu_{0} \mathrm{E} / c_{1}{ }^{2} \bar{v}_{0}=-1.0\left(\mathrm{cal} \cdot \mathrm{cm}^{3} \cdot \mathrm{g}^{-2}\right)$

(11) $T \Delta s_{0}{ }^{\mathrm{E}} / c_{1}^{2} \bar{v}_{0}=-6.8\left(\mathrm{cal} \cdot \mathrm{cm}^{3} \cdot \mathrm{g}^{-2}\right)$

(10) $\Delta h_{0} \mathrm{E} / c_{1}^{2} \bar{v}_{0}=-7.8\left(\mathrm{cal} \cdot \mathrm{cm}^{3} \cdot \mathrm{g}^{-2}\right)$

いくつかの溶媒について， $A_{2}$ および $[\eta]$ を測定し，その関係を検討した。

\section{1 緒言}

ポリカーボネート (PC) は, 下記のように, その構造が二つの フェニル基より成るかさばった部分とその回転性がかなり自由な ー0- 結合をもつ部分とより成るために, ビニル系ポリマーとセ ルロース誘導体との中間的な挙動を示すことが期待される。<smiles>CC(=O)Oc1ccc(C(C)C)cc1</smiles>

*1 Shinya Teramachi, Akira TAKAhashi, Ikumi KAGAWA 名古屋大学工学部応用化学科：名古屋市千種区不艺 町.
Schulz, Horbach ${ }^{1)}$ は，良溶媒中での光散乱測定および摩擦的 性質からの計算によって分子の広がりを求め，Zimm，Stockmayer 抢よび Fixman²) の理論から unperturbed dimension を推 定した。これによって，PC は，その広がりに関して，七ルロ一 ス誘導体とパラフィン置換体ポリマーとの中間にあることが示さ れた。彼らは, PC の比較的大きな広がりは, 内部回転の障害に よるのではなく，その鎖員の長さが，大きいことによるとしてい る。

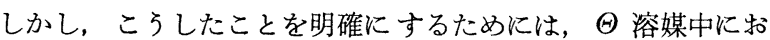
ける unperturbed dimension を測定し，ポリマー鎖の conformation や鎖の自由回転性に対する障害の程度を見積ることが必

1) G. V. Schulz and A. Horbach, Makromol. Chem., 29, 93 (1959).

2) B. H.Zimm, W. Stockmayer, M. Fixman, J. Chem. Phys., 21, 1716 (1953). 